\title{
Ten Challenges of the Amyloid Hypothesis of Alzheimer's Disease
}

\section{Kepp, Kasper Planeta}

Published in:

Journal of Alzheimer's Disease

Link to article, DOI:

10.3233/JAD-160550

Publication date:

2017

Document Version

Peer reviewed version

Link back to DTU Orbit

Citation (APA):

Kepp, K. P. (2017). Ten Challenges of the Amyloid Hypothesis of Alzheimer's Disease. Journal of Alzheimer's Disease, 55(2), 447-457. https://doi.org/10.3233/JAD-160550

\section{General rights}

Copyright and moral rights for the publications made accessible in the public portal are retained by the authors and/or other copyright owners and it is a condition of accessing publications that users recognise and abide by the legal requirements associated with these rights.

- Users may download and print one copy of any publication from the public portal for the purpose of private study or research.

- You may not further distribute the material or use it for any profit-making activity or commercial gain

- You may freely distribute the URL identifying the publication in the public portal

If you believe that this document breaches copyright please contact us providing details, and we will remove access to the work immediately and investigate your claim. 


\title{
Ten Challenges of the Amyloid Hypothesis of Alzheimer's Disease
}

\author{
Kasper Planeta Kepp* \\ Technical University of Denmark, DTU Chemistry, DK-2800 Kongens Lyngby, Denmark \\ *Correspondence: Email: kpj@kemi.dtu.dk Phone: +45 45252409
}

\begin{abstract}
The inability to effectively halt or cure Alzheimer's Disease (AD), exacerbated by the recent failures of high-profile clinical trials, emphasizes the urgent need to understand the complex biochemistry of this major neurodegenerative disease. In this paper, ten central, current challenges of the major paradigm in the field, the amyloid hypothesis, are sharply formulated. These challenges together show that new approaches are necessary that address data heterogeneity, increase focus on the proteome level, use available human patient data more actively, account for the aging phenotype as a background model of the disease, unify our understanding of the interplay between genetic and non-genetic risk factors, and combine into one framework both the familial and sporadic forms of the disease.
\end{abstract}

\section{Keywords: Alzheimer's Disease, amyloid hypothesis, challenges, toxicity, aging}




\section{Introduction}

Alzheimer's Disease (AD) is one of the major health challenges of the 21st century: Based on data from the World Health Organization[1] and Alzheimer International[2], one can estimate that 30 million people have AD world-wide as of 2016, and prevalence continues to grow. In 2010, a meta-analysis estimated 35.6 million dementia cases[3], corresponding to 21-25 million AD cases $(60-70 \%$ of dementia cases are classified as $A D)$, implying an annual growth in prevalence of $1 \frac{1}{2} 2$ million. The persistent deterioration associated with the disease is devastating to patients and relatives alike, and the prospected socio-economic burden of $\mathrm{AD}$ in an increasingly aged population threatens to undermine future healthcare budgets[4].

In the wake of the early successes of the major mechanistic AD paradigm, the amyloid hypothesis[5][6], the field has experienced clinical disappointments, biochemical confusions, and new arising theories[7][8][9]. Accordingly, our ability to treat the disease remains deeply unsatisfactory, with current treatments only delaying disease progression by months[10][11]. The recent failure of high-profile drug candidates has been a painful wake-up call that has intensified the debate regarding disease mechanisms and treatment strategies[7][8][12][13].

$\mathrm{AD}$ is a complex multi-factor disease: It occurs mostly sporadically ( $>95 \%$ of cases) with very limited inheritance, it has a broad clinical spectrum[14], age is the main risk factor[15], and the disease manifests slowly as mild cognitive impairment[14][16][17] and subsequently leads to loss of cognitive capabilities, identity, and activity[18][19]. The complexity is evident from the multiple genetic, life-style, and environmental risk modifiers[20][21].

Genetic variations in the genes coding for the amyloid- $\beta$ protein precursor (APP)[22] and the two presenilin isoforms PSEN1 and PSEN2[23][24] cause special early-onset familial forms of $\mathrm{AD}(\mathrm{FAD})[25][26][27]$. Thus, APP and PSEN have constituted the main basis for 
understanding $\mathrm{AD}$, leading to the amyloid hypothesis discussed in this paper[6][28][29]. In addition, the apolipoprotein E $\varepsilon 4$ allele (ApoE4) increases risk by several times for heterozygote carriers and by up to 15-fold for homozygotes[30][31][32]. Many other DNA loci have been identified from genome-wide association studies (GWAS) to possibly confer some risk of $\mathrm{AD}[33][34]$. Some notable ones are BIN1, GAB2, GALP, ABCA7, TNK1, TREM2, PICALM, and $C L U$; many of these are involved in membrane transport, endocytosis, immune system, and/or lipid metabolism[25][34][35][36][37].

Among life-style related risk factors associated with dementia (but not yet clearly separated from AD), the most important are smoking[38], alcohol usage[39][40], body mass index[41][42], diabetes[43][44], hypertension[45], physical and mental inactivity[46][47][48], and depression[49][50]. Activity and education[20][51] and particular diets such as anti-oxidantrich Mediterranean and Indian cuisines[52][53][54] can reduce risk of dementia[55][56][57].

\section{The amyloid hypothesis}

The $A \beta$ peptides that constitute the plaques characteristically found in patients have historically been a natural starting point for understanding the disease. A $\beta$ is produced from APP found in the membranes of cells and organelles upon protein cleavage by $\beta$ - and $\gamma$-secretases[58][59]. Furthermore, PSEN is the catalytic unit of the $\gamma$-secretase complex that degrades (among other substrates such as Notch[60]) APP into A $\beta[61]$. Thus, the two major genetic risks of FAD, PSEN and APP, suggest a role of $A \beta$ in $A D$, providing support for the dominating paradigm of $A D$, the amyloid hypothesis[6][28].

The early version of the amyloid hypothesis, often referred to as the amyloid cascade hypothesis[5][28], asserted that toxic A $\beta$-overload is the cause of AD: It was inspired by the 
observed amyloid deposits in $\mathrm{AD}$ brains that could suggest an overload mechanism at play[62]. The finding that the plaques consist of $A \beta$ peptides provided support for the amyloid hypothesis[63]. Plaque deposits constitute several years of total production of $\mathrm{A} \beta$, and the steady-state equilibrium between production and clearance of $A \beta$ is maintained at kinetic rates of $\sim 8 \%$ per hour[64]. Vascular transport of $\mathrm{A} \beta$ across the blood-brain barrier can control $\mathrm{A} \beta$ brain levels and is impaired upon aging[65][66][67]; this clearance is reduced in $\mathrm{AD}[68]$. This equilibrium has been thought to be perturbed to gradually increase steady-state levels of toxic $A \beta$ consistent with the buildup of plaques[28]. This version of the hypothesis was a quantitative gain of toxic function (or "toxic by degree") mechanism, i.e. quantitative levels were seen as a defining culprit of disease, supported by the major plaque deposits.

However, many FAD-causing mutations in PSEN1 do not generally increase A $\beta$ production but actually often lower it[58][69]. Neuro-degeneration and cognitive decline does not correlate with the amount of $\mathrm{A} \beta$ plaques[11,12]. Also, $20-40 \%$ of cognitively normal people have $A \beta$ plaques in amounts typical for the disease[70]. Thus, total $A \beta$ load, which is dominated by the extracellular plaque pool, relates little to disease progress. This led to modification of the paradigm to imply that not the total $A \beta$ levels, but the ratio between long and short forms of $A \beta$ (mostly $\mathrm{A} \beta_{42} / \mathrm{A} \beta_{40}$ ) are molecular determinants of disease[29][71]; $\mathrm{A} \beta_{42}$ is well-established to be more toxic than $A \beta_{40}[6][9]$, so this argument had support.

Soluble oligomers of $A \beta$, as first reported by Yankner et al.[72], are more cytotoxic than the fibrils making up the major $\mathrm{A} \beta$ plaques[73][74]. The toxicity of oligomers is very dependent on size and conformation[75], and both $A \beta$-dimers and trimers[76] have been identified as particularly toxic[77]. Yet, the assignment of a single pathogenic form and mechanism of $A \beta$ remains elusive[78][79]. However recently, toxicities of genetic $A \beta$ variants were found to 
correlate significantly with conformational features of the peptide variants, with disordered coil structures being more toxic[80]. The toxicity of oligomers depends on structural features as the peptide converts from unstructured monomer to the increasingly $\beta$-sheet structured oligomers[81]; these findings suggest that qualitative, rather than quantitative, features of A $\beta$ can in principle cause disease (i.e. "toxic by kind").

The toxic mechanism of $A \beta_{42}$-enriched oligomers supposedly causing $\mathrm{AD}$ remains highly debated, and several toxic modes of action have been suggested[82]: They may lead to impairment of long-term potentiation[83], permeabilization of cell membranes[84][85], oxidative stress[86], and calcium dyshomeostasis[87][88]. Exposure of hydrophobic parts of the $\mathrm{A} \beta$ variants is likely to cause aggregation and, in various contexts, interactions with membranes and other molecules in the cell to aggravate the toxicity of the peptides[85][89][90]. A $\beta$ has a hydrophilic and a hydrophobic part well-suited for membrane interaction, and multiple studies have documented interaction with membranes[84][85][91] and disruption of prion-protein interaction with NMDA receptors[92] and of the respiratory chains of mitochondria[93][94][95].

Many of the characterized FAD-causing mutations in PSEN1 impair $\gamma$-secretase function while increasing the $A \beta_{42} / A \beta_{40}$ ratio[69][96]; some do so while increasing, others while decreasing total $A \beta$ levels which are dominated by the $A \beta_{40}$ isoform[97][98]. Indeed, increased proficiency of so many mutations would be a priori unlikely, as proteins are optimized by evolution to perform optimally under the constraints given, and thus most mutations tend to be hypomorphic[99]. PSEN1 mutations also tend to be dominant, i.e. heterozygote carriers are likely to develop $\mathrm{AD}$; this feature is usually interpreted as a gain-of-toxic function because the compensatory presence of the wild type does not prevent disease[69]. Thus, the rationale for inhibiting $\gamma$-secretase in the first place, to create phenotypes resembling the FAD-causing 
mutants, seems questionable, and indeed, such inhibitors have produced adverse cognitive effects[13][100].

The amyloid hypothesis has recently been reviewed and arguments in its favor have been compiled[101]. The reader may view the present paper as a counter view to the idea that a gain of function of $\mathrm{A} \beta$ causes $\mathrm{AD}$ and that therapeutic strategies should accordingly focus on $\mathrm{A} \beta$ containment.

\section{Ten challenges of the amyloid hypothesis}

Among challenges of the amyloid hypothesis, the following ten may be considered noteworthy:

(i) The "normal plaques" anomaly: 20-40\% of normal elderly have been found by Aizenstein et al. to possess high loads of $\mathrm{A} \beta$ plaques[70], and many such people have enough plaques to satisfy common AD diagnosis criteria[102][103]; this anomaly was frequently mentioned[8][104][105]. The amyloid-centric solution to this anomaly is that these normal deposits represent pre-clinical disease states[106]; this hypothesis remains to be tested by carefully monitoring cognitively normal people for emerging clinical indications of AD over several years, correlated against measured plaque load. However, many of these plaques are diffuse and not directly related to pathogenicity[101]; thus the significance of the plaque deposits to disease progress needs to be further addressed.

This challenge also relates to the quality of biomarkers: The A $\beta$-related biomarkers currently used are $A \beta_{42}$ levels in the cerebrospinal fluid and Positron Emission Tomography (PET) imaging of A $\beta$ plaque deposits[111], which usually accompanies AD diagnosis[18][402]; this method identifies $A \beta$ deposition early in $A D$ pathology, in support of a role of $A \beta$ imbalance in $\mathrm{AD}[101]$. However, plaque deposits are no longer considered pathogenic 
themselves[106][107][108][109]. Furthermore, the tendency to form plaque-like aggregates does not correlate with clinical severity of a $\mathrm{A} \beta$ variants[9], and plaques are less toxic than various intracellular forms of $A \beta[112][113][114][115]$. PET does not primarily measure the supposedly pathogenic forms of $A \beta[72]$, since these forms differ substantially in size and structure[75][76][77]. In addition, it is unlikely that the current therapies target the oligomer types A $\beta$ that cause disease[78][79]. Thus, while PET imaging clearly provides important insight into disease features, we need to know much more about the specific molecular forms of $\mathrm{A} \beta$ relevant to different stages of the disease[117][118].

(ii) The A $\beta$-localization-neurodegeneration anomaly: $\mathrm{A} \beta$ is expressed throughout the brain, but $\mathrm{AD}$ initiates in specific parts of the brain, i.e. additional factors contribute to disease, as first observed by Gomez-Isla et al.[107] and later confirmed by Schmitz al.[108]. This point was cited as an anomaly by Bush and Tanzi[109] and has been repeated in later lists of anomalies[8][104][105]. The missing factors explaining why some areas are first hit by AD need to be accounted for.

(iii) The neglect of normal function: The normal functions of the central players, $A \beta$ and APP, are not incorporated into the current form of the amyloid hypothesis, although A $\beta$ serves beneficial roles in the normal brain[110][111]. The presence of normal functions of $A \beta$ complicates the idea that $\mathrm{A} \beta$ is simply a toxic peptide whose overload triggers $\mathrm{AD}[112]$. $\mathrm{A} \beta$ has a therapeutic window, with concentrations below nano-molar (as encountered within cells) being neurotrophic and higher concentrations (as seen in research models of the disease) being toxic[113][114], yet the amyloid hypothesis[101] focuses only on one side of this equation. Normal functions of $A \beta$ are documented in multiple studies: Loss of $A \beta_{40}$ upon secretase inhibition or $\mathrm{A} \beta$ antibodies kills cultured neurons[115] and impairs neuronal activity in 
mice[110]. A $\beta$ may also protect against metal-induced toxicity[111] and regulate vesicle release in hippocampal synapses[116]. Also, the innate immune system[117][118] and pathogen responses[119] are related to $A \beta$ imbalances, and $A \beta$ can act as a pro-inflammatory agent in such cases[120]. The recently identified roles of infections in elevating AD risk show that inflammatory trauma plays a major role in AD pathology[121][122][123][124]. Clearly, the functions of and responses to $A \beta$ within the neurons are still very far from understood and substantially more complicated than the current overload mechanism implies.

(iv) The divide between familial and sporadic $A D$ : The amyloid hypothesis is essentially a FAD hypothesis: It is based on inherited mutations in APP and PSEN and its research models involve such genetic mutations known to overexpress $A \beta$. This approach is very narrow and certainly does not accurately depict the $\sim 95 \%$ sporadic cases caused by risk factors not relating to $A \beta$, which should be explained. There is thus an urgent need to understand in combination the biochemical causes of the two forms of disease, e.g. by developing sporadic models of AD based on chemical-aging instead of mutations.

v) Data heterogeneity reduces interpretative value of disease models based on APP variants: A main basis for the amyloid hypothesis is the overexpression of FAD-related APP mutations in cells and mice. These mutations are located both within (e.g. the Dutch and Italian mutation) and outside (e.g. the Swedish mutation) the $\mathrm{A} \beta$ region[9]. The protective A2T mutation[125] has been widely used as a showcase of the amyloid hypothesis[101], and its lower produced $A \beta$ levels fit well to quantitative gain of function as the protective alternative to the Swedish mutation and A2V[126]. The Swedish mutation produces very high A $\beta$ levels and is the most used transgenic mouse model in AD research[127], yet it only models the type of overproduction of $A \beta$ consistent with the now obsolete "cascade" hypothesis. 
However, the phenotypes of APP variants are very heterogeneous, a fact sometimes overlooked when focusing on a specific variant[9]. Some of these mutations increase the $A \beta_{42} / A \beta_{40}$ ratio, others lower it. Some are more toxic than wild-type forms, others not significantly so. Some aggregate quickly, others relatively slowly. The $\mathrm{EC}_{50}$ values of $\mathrm{A} \beta$ variants vary substantially and do not correlate with clinical disease characteristics, and reported aggregation propensities are challenged by measurement uncertainties and differences in lab protocols[9]. This implies that the widely used research models have little, if anything, to do with the gradually disturbed amyloid imbalances of the aging human brain[9]. Even in terms of clinical manifestation, APP variations can give rise to either cerebral amyloid angiopathy (CAA) or classical $\mathrm{AD}$, reflected in differences in the intensity of tangles and plaques[9]. This biochemical and clinical heterogeneity is not accounted for by the amyloid hypothesis, which tends to focus on transgenic models where amyloid levels are uniformly increased, a model that presumes quantitative, rather than qualitative, gain of function.

The trisomy 21 AD-related phenotype is often cited in support of the amyloid hypothesis as a clear-cut case of quantitative gain of function[101]. However, if one looks at the APP phenotypes in total, quantitative gain cannot by itself explain $\mathrm{AD}$ as many mutations in both APP and PSEN1 do not increase A $\beta$ levels[9]. Also, A2V, H6R, and D7N variants (using A $\beta$ numbering) lead to $A \beta_{42} / A \beta_{40}$ ratios similar to wild type, but E22G, E22K, and E22Q actually lower the $A \beta_{42} / A \beta_{40}$ ratio[9]. Still, drug development programs are directed towards reducing the amount of $\mathrm{A} \beta$ based on a quantitative gain of function mechanism that clearly does not represent the multitude of manifestations of the FAD mutant phenotypes. The phenotypes of APP variants in their totality strongly suggest that overexpression is a side effect of some APP mutations, but not itself the cause of disease[9]. 
vi) Toxicity does not reflect pathogenicity: The amyloid hypothesis lends support from specific $A \beta$ toxicities measured in cultured cells. Many reported $A \beta$ cytotoxicities[128] and aggregation tendencies[129] occurred at micro-molar concentrations, representative of $\sim 1$ year of total brain production, administered locally and instantaneously at 1000-fold higher than biological concentrations[130][131]; yet the true human disease is age-dependent and only manifest very gradually. Arguably, many amyloid toxicity studies simply prove the principle of Paracelsus that the dose makes the poison and are hardly informative. Some toxic modes associated with physiologically relevant concentrations have been reported[76], and more research in this direction seems required. Yet, quantitative measures of clinical severity (age of onset, survival times) of genetic $A \beta$ variants do not correlate with measured toxicities[9]. Thus, any relation between toxicity in cells and mice and the real human aging brain disease remains speculative and potentially explains why such research models have not produced successful clinical treatments.

(vii) The absence of genetic risk factors relating to $A \beta$ turnover: Many more mutations in PSEN1 than in APP cause AD, although APP contains the final A $\beta$ product; this anomaly was first emphasized by Shen and Kelleher[132]. Also, the shortage of $\beta$ - and $\alpha$-secretase mutations and mutations in zinc peptidases such as insulin degrading enzyme involved in amyloid degradation undermine the concept that APP cleavage and A $\beta$ production is central to disease. The FAD-related mutations, and in particular the absent FAD-related mutations, argue for a secondary role of APP processing (and hence, amyloid buildup) relative to other functions.

(viii) The curious nature of the $A \beta_{42} / A \beta_{40}$ ratio: Many FAD mutations tend to lower the levels of both amyloid isoforms, and the amyloid hypothesis relies on the $A \beta_{42} / A \beta_{40}$ ratio to argue why PSEN mutations cause AD[13][133], yet the curious nature of only this ratio (but not 
total levels of $A \beta_{42}$ ) being pathogenic remains to be explained, i.e. how does this produce gradual buildup of toxic oligomers emphasized by the amyloid hypothesis[133]. This ratio has recently been directly correlated to clinical severity, although this does not necessarily imply causation[97]. It could be that reduced enzymatic function causes disease and that higher ratios is a side consequence[132][134].

Some possible solutions to this anomaly can be suggested: A competitive seeding that depends on relative amounts of isoforms rather than total $A \beta_{42}$ levels (which tend to also decrease in PSEN1 phenotypes) could mean that local surplus of longer isoforms seed degradation-resistant oligomers that enable a gradual buildup of oligomers. Also, one could imagine that hetero-oligomers enriched in longer isoforms may be less prone to degradation, thus causing a gradual buildup of pathogenic oligomer pools. Such mechanisms could demystify the $\mathrm{A} \beta_{42} / \mathrm{A} \beta_{40}$ ratio as a culprit of disease and provide it with a mechanistic basis.

(ix) The aging effect: The amyloid hypothesis does not explain the main risk factor, age, i.e. why $\mathrm{A} \beta$ gradually accumulates but then transits into gradual cognitive impairment and $\mathrm{AD}$, as emphasized by the two-hit hypothesis[135]. The aging human proteome undergoes remarkably systematic changes with a general down-regulation of genes involved in synaptic function, including calcium homeostasis and vesicular transport, whereas genes involved in stress response, inflammation, lipid metabolism are generally up-regulated[15]. These features should be incorporated into models of $\mathrm{AD}$ to capture the aging effect, yet the amyloid hypothesis has little direct coupling to the aging phenotype. At the same time, the other important histopathological features of $\mathrm{AD}$ that relate more directly to chemical aging, e.g. metabolic deficiencies, metal ion imbalances, and oxidative stress, are not well accounted for by the amyloid hypothesis[104], and these manifestations need also to be explained in relation to amyloid imbalance. 
(x) Clinical performance: The ultimate test of any disease theory, the development of medicine from the principles of the ruling paradigm, has not yet been successful[7][12]; the absence of any $A \beta$-centric drug on the market or indeed any successful phase 3 trial has led to calls for modification of the amyloid hypothesis[11]. The most promising current drug candidates are antibodies such as solanezumab that target various $A \beta$ forms[136]. Solanezumab did not improve cognitive function in the two major phase 3 trials[137], but if one analyses the combined data there is a positive effect on cognition that should be explored further[138][139]. Aducanumab has also shown several promising data and is currently a promising candidate[140][141]. However, another antibody, Bapineuzumab, has been found not to improve cognition[142] and produce adverse effects[143] even though it does lower A $\beta$ levels[144]. Clearly, we need to understand better these different outcomes, specifically how the various antibodies bind and modify the conformations and properties of $A \beta$, as the various conformations of $\mathrm{A} \beta$ that are targeted affect pathology differently[7][80].

In many of these cases, the clinical human data were substantially less encouraging than the mouse and cell data used to research new treatments[13][100], a troubling finding that is however consistent with the poor correlations between human and cell and mouse data from meta-analysis[9]. This problem emphasizes two major challenges in current AD research; the need for accurate models of the conformational epitopes targeted by therapies and the need for preclinical disease models that more accurately reflect the aging human brain.

\section{Concluding remarks and perspectives}

The ten challenges above emphasize that new approaches are required if the amyloid paradigm is to be retained. While the heterogeneity in clinical data is due to risk modifiers and thus a 
problem to any paradigm of $\mathrm{AD}$, heterogeneity in $\mathrm{A} \beta$-specific data is due to different lab protocols and to the special chemical features of this enigmatic peptide: Efforts are ongoing to produce consistent, stable, and reproducible monomeric and oligomeric A $\beta$ samples to remove some of the protocol-based heterogeneity[145][146]. Even beyond sample management, the structural variability of these highly disordered peptides[147] renders observed properties such as toxicity very conformation-dependent, and, since conformation relates to chemical environment, observed properties are highly sensitive to concentration, $\mathrm{pH}$, ionic strength, cosolvents, and the time scale of the experiment[90][148].

Considering the major structural variability of $A \beta$, the "physiologically relevant" $A \beta$ structures can be sought by correlating specific structures directly to clinical and biochemical data: This provides statistically significant relationships between fundamental chemical properties of $A \beta$ variations and their clinical and biochemical phenotypes[80][90][149]: Remarkably, hydrophobic exposure in disordered structures correlates with the diagnosis age of patients carrying a specific variant, whereas other structures do not. This suggests that these disordered conformations of $A \beta$ are the physiologically relevant ones[149]. Also, the differences in experimental $\mathrm{A} \beta$ toxicities can be explained by distinct structural features, notably the amount of hydrophobic exposure seen in the average structural ensemble of each peptide variant, providing statistically significant correlations to $\mathrm{EC}_{50}$ data[80][90]. Thus, $\mathrm{A} \beta$ aggregation and cell toxicity is caused by hydrophobic exposure in specific disordered amyloid states that could be targeted by molecular intervention, e.g. antibodies[150][151]. However, in the light of the poor correlation between toxicity assays and clinical disease features[9], the question still remains whether this oligomerization-driven cell toxicity has anything to do with AD.

To move forward on these various challenges, we must i) solve the data heterogeneity issue of peptide preparations and measurements; ii) actively use available human patient data 
that tell us about the real aging human disease, considering the challenges of mouse models[127]; iii) unite sporadic and familial disease forms as we move beyond the FADmutation-based research models and towards chemical-aging models that account for the aging phenotype as emphasized e.g. by the two-hit hyopothesis[135]; iv) think effectively at the proteome rather than single-gene level; v) account for the normal functions of APP and A $\beta$, as their absence within the current paradigm is conspicuous; the elaborate splicing of APP clearly occurs in the neurons for a reason; and vi) consider all manifestations of disease, including oxidative stress and metal ion imbalances, mitochondrial disease, immune system responses, and metabolic deficiencies.

The amyloid paradigm may have been an excellent starting point, but it is, as argued above, very far from the full solution. 


\section{Conflict of interest statement}

The author reports no conflicts of interest.

\section{References}

[1] World Health Organization (2015) Fact sheet on dementia.

[2] Alzheimer's Disease International (2015) World Alzheimer Report 2015: The Global Impact of Dementia.

[3] Prince M, Bryce R, Albanese E, Wimo A, Ribeiro W, Ferri CP (2013) The global prevalence of dementia: a systematic review and metaanalysis. Alzheimers. Dement. 9, 63-75.e2.

[4] Karlawish J (2011) Addressing the ethical, policy, and social challenges of preclinical Alzheimer disease. Neurology 77, 1487-1493.

[5] Hardy JA, Higgins GA (1992) Alzheimer's disease: the amyloid cascade hypothesis. Science 256, 184-185.

[6] Hardy J, Selkoe DJ (2002) The amyloid hypothesis of Alzheimer's disease: progress and problems on the road to therapeutics. Science 297, 353-356.

[7] Rosenblum WI (2014) Why Alzheimer trials fail: Removing soluble oligomeric beta amyloid is essential, inconsistent, and difficult. Neurobiol. Aging 35, 969-974.

[8] Herrup K (2015) The case for rejecting the amyloid cascade hypothesis. Nat Neurosci 794-799.

[9] Tiwari MK, Kepp KP (2016) $\beta$-Amyloid pathogenesis: Chemical properties versus cellular levels. Alzheimer's Dement. J. Alzheimer's Assoc. 12, 184-194. 
[10] Goedert M, Spillantini MG (2006) A century of Alzheimer's disease. Science 314, 777781.

[11] Sorrentino P, Iuliano A, Polverino A, Jacini F, Sorrentino G (2014) The dark sides of amyloid in Alzheimer's disease pathogenesis. FEBS Lett. 588, 641-652.

[12] Teich AF, Arancio O (2012) Is the Amyloid Hypothesis of Alzheimer's disease therapeutically relevant? Biochem. J. 446, 165-177.

[13] De Strooper B, Chávez Gutiérrez L (2015) Learning by Failing: Ideas and Concepts to Tackle $\gamma$-Secretases in Alzheimer's Disease and Beyond. Annu. Rev. Pharmacol. Toxicol. 55, 419-437.

[14] Karantzoulis S, Galvin JE (2011) Distinguishing Alzheimer's disease from other major forms of dementia. Expert Rev. Neurother. 11, 1579-1591.

[15] Lu T, Pan Y, Kao S-Y, Li C, Kohane I, Chan J, Yankner BA (2004) Gene regulation and DNA damage in the ageing human brain. Nature 429, 883-891.

[16] Bäckman L, Jones S, Berger AK, Laukka EJ, Small BJ (2004) Multiple cognitive deficits during the transition to Alzheimer's disease. J. Intern. Med. 256, 195-204.

[17] Arnáiz E, Almkvist O (2003) Neuropsychological features of mild cognitive impairment and preclinical Alzheimer's disease. Acta Neurol. Scand. 107, 34-41.

[18] Blennow K, de Leon MJ, Zetterberg H (2015) Alzheimer's disease. Lancet 368, 387-403.

[19] McKhann GM, Knopman DS, Chertkow H, Hyman BT, Jack Jr. CR, Kawas CH, Klunk WE, Koroshetz WJ, Manly JJ, Mayeux R, Mohs RC, Morris JC, Rossor MN, Scheltens P, Carrillo MC, Thies B, Weintraub S, Phelps CH (2011) The diagnosis of dementia due to 
Alzheimer's disease: Recommendations from the National Institute on Aging-Alzheimer's Association workgroups on diagnostic guidelines for Alzheimer's disease. Alzheimer's Dement. 7, 263-269.

[20] Beydoun MA, Beydoun HA, Gamaldo AA, Teel A, Zonderman AB, Wang Y (2014) Epidemiologic studies of modifiable factors associated with cognition and dementia: systematic review and meta-analysis. BMC Public Health 14, 643.

[21] Mayeux R (2003) Epidemiology of neurodegeneration. Annu. Rev. Neurosci. 26, 81-104.

[22] Goate A, Chartier-Harlin MC, Mullan M, Brown J, Crawford F, Fidani L, Giuffra L, Haynes A, Irving N, James L (1991) Segregation of a missense mutation in the amyloid precursor protein gene with familial Alzheimer's disease. Nature 349, 704-706.

[23] Sherrington R, Rogaev EI, Liang Y, Rogaeva EA, Levesque G, Ikeda M, Chi H, Lin C, Li G, Holman K, Tsuda T, Mar L, Foncin JF, Bruni AC, Montesi MP, Sorbi S, Rainero I, Pinessi L, Nee L, Chumakov I, Pollen D, Brookes A, Sanseau P, Polinsky RJ, Wasco W, Da Silva HA, Haines JL, Perkicak-Vance MA, Tanzi RE, Roses AD, Fraser PE, Rommens JM, St George-Hyslop PH (1995) Cloning of a gene bearing missense mutations in earlyonset familial Alzheimer's disease. Nature 375, 754-760.

[24] Levy-Lahad E, Wasco W, Poorkaj P, Romano DM, Oshima J, Pettingell WH, Yu CE, Jondro PD, Schmidt SD, Wang K, et al. (1995) Candidate gene for the chromosome 1 familial Alzheimer's disease locus. Science 269, 973-977.

[25] Hollingworth P, Harold D, Jones L, Owen MJ, Williams J (2011) Alzheimer's disease genetics: Current knowledge and future challenges. Int. J. Geriatr. Psychiatry 26, 793802. 
[26] Ryman DC, Acosta-Baena N, Aisen PS, Bird T, Danek A, Fox NC, Goate A, Frommelt P, Ghetti B, Langbaum JBS, Lopera F, Martins R, Masters CL, Mayeux RP, McDade E, Moreno S, Reiman EM, Ringman JM, Salloway S, Schofield PR, Sperling R, Tariot PN, Xiong C, Morris JC, Bateman RJ (2014) Symptom onset in autosomal dominant Alzheimer disease: A systematic review and meta-analysis. Neurology 83, 253-260.

[27] Campion D, Dumanchin C, Hannequin D, Dubois B, Belliard S, Puel M, ThomasAnterion C, Michon A, Martin C, Charbonnier F, Raux G, Camuzat A, Penet C, Mesnage V, Martinez M, Clerget-Darpoux F, Brice A, Frebourg T (1999) Early-onset autosomal dominant Alzheimer disease: prevalence, genetic heterogeneity, and mutation spectrum. Am. J. Hum. Genet. 65, 664-670.

[28] Hardy J (2006) Alzheimer's disease: The amyloid cascade hypothesis - An update and reappraisal. J. Alzheimer's Dis. 9, 151-153.

[29] Karran E, Mercken M, De Strooper B (2011) The amyloid cascade hypothesis for Alzheimer's disease : an appraisal for the development of therapeutics. Nat. Rev. Drug Discov. 10, 698-712.

[30] Corder EH, Saunders AM, Strittmatter WJ, Schmechel DE, Gaskell PC, Small GW, Roses AD, Haines JL, Pericak-Vance MA (1993) Gene dose of apolipoprotein E type 4 allele and the risk of Alzheimer's disease in late onset families. Science 261, 921-923.

[31] Kim KY, Wood BE, Wilson MI (2005) Risk factors for Alzheimer's diseases: An overview for clinical practitioners. Consult. Pharm. 20, 224-230.

[32] Bickeböller H, Campion D, Brice a, Amouyel P, Hannequin D, Didierjean O, Penet C, Martin C, Pérez-Tur J, Michon a, Dubois B, Ledoze F, Thomas-Anterion C, Pasquier F, 
Puel M, Demonet JF, Moreaud O, Babron MC, Meulien D, Guez D, Chartier-Harlin MC, Frebourg T, Agid Y, Martinez M, Clerget-Darpoux F (1997) Apolipoprotein E and Alzheimer disease: genotype-specific risks by age and sex. Am. J. Hum. Genet. 60, 439446.

[33] Medway C, Morgan K (2014) Review: The genetics of Alzheimer's disease; putting flesh on the bones. Neuropathol Appl Neurobiol 40, 97-105.

[34] Bertram L, Tanzi RE (2009) Genome-wide association studies in Alzheimer's disease. Hum. Mol. Genet. 18, R137-R145.

[35] Harold D, Abraham R, Hollingworth P, Sims R, Gerrish A, Hamshere ML, Pahwa JS, Moskvina V, Dowzell K, Williams A, Jones N, Thomas C, Stretton A, Morgan AR, Lovestone S, Powell J, Proitsi P, Lupton MK, Brayne C, Rubinsztein DC, Gill M, Lawlor B, Lynch A, Morgan K, Brown KS, Passmore PA, Craig D, McGuinness B, Todd S, Holmes C, Mann D, Smith AD, Love S, Kehoe PG, Hardy J, Mead S, Fox N, Rossor M, Collinge J, Maier W, Jessen F, Schurmann B, Heun R, van den Bussche H, Heuser I, Kornhuber J, Wiltfang J, Dichgans M, Frolich L, Hampel H, Hull M, Rujescu D, Goate AM, Kauwe JSK, Cruchaga C, Nowotny P, Morris JC, Mayo K, Sleegers K, Bettens K, Engelborghs S, De Deyn PP, Van Broeckhoven C, Livingston G, Bass NJ, Gurling H, McQuillin A, Gwilliam R, Deloukas P, Al-Chalabi A, Shaw CE, Tsolaki M, Singleton AB, Guerreiro R, Muhleisen TW, Nothen MM, Moebus S, Jockel K-H, Klopp N, Wichmann H-E, Carrasquillo MM, Pankratz VS, Younkin SG, Holmans PA, O’Donovan M, Owen MJ, Williams J (2009) Genome-wide association study identifies variants at CLU and PICALM associated with Alzheimer's disease. Nat. Genet. 41, 1088-1093.

[36] Lambert J-C, Heath S, Even G, Campion D, Sleegers K, Hiltunen M, Combarros O, 
Zelenika D, Bullido MJ, Tavernier B, Letenneur L, Bettens K, Berr C, Pasquier F, Fievet N, Barberger-Gateau P, Engelborghs S, De Deyn P, Mateo I, Franck A, Helisalmi S, Porcellini E, Hanon O, de Pancorbo MM, Lendon C, Dufouil C, Jaillard C, Leveillard T, Alvarez V, Bosco P, Mancuso M, Panza F, Nacmias B, Bossu P, Piccardi P, Annoni G, Seripa D, Galimberti D, Hannequin D, Licastro F, Soininen H, Ritchie K, Blanche H, Dartigues J-F, Tzourio C, Gut I, Van Broeckhoven C, Alperovitch A, Lathrop M, Amouyel P (2009) Genome-wide association study identifies variants at CLU and CR1 associated with Alzheimer's disease. Nat. Genet. 41, 1094-1099.

[37] Karch CM, Goate AM (2015) Alzheimer's disease risk genes and mechanisms of disease pathogenesis. Biol. Psychiatry 77, 43-51.

[38] Reitz C, den Heijer T, van Duijn C, Hofman A, Breteler MMB (2007) Relation between smoking and risk of dementia and Alzheimer disease - The Rotterdam Study. Neurology 69, 998-1005.

[39] Ruitenberg A, van Swieten JC, Witteman JCM, Mehta KM, van Duijn CM, Hofman A, Breteler MMB (2002) Alcohol consumption and risk of dementia: the Rotterdam Study. Lancet 359, 281-286.

[40] Vincze G, Almos P, Boda K, Doeme P, Bodi N, Szlavik G, Magloczki E, Pakaski M, Janka Z, Kalman J (2007) Risk factors of cognitive decline in residential care in Hungary. Int. J. Geriatr. Psychiatry 22, 1208-1216.

[41] Whitmer RA, Gunderson EP, Quesenberry CP, Zhou J, Yaffe K (2007) Body mass index in midlife and risk of Alzheimer disease and vascular dementia. Curr. Alzheimer Res. Curr. Alzheimer Res, Curr Alzh R, Curr Alzheimer Res 4, 103-109. 
[42] Kivipelto M, Ngandu T, Fratiglioni L, Viitanen M, Kåreholt I, Winblad B, Helkala EL, Tuomilehto J, Soininen H, Nissinen A (2005) Obesity and vascular risk factors at midlife and the risk of dementia and Alzheimer disease. Arch. Neurol. Arch. Neurol, Arch Neurol, Arch Neurol Chicago, Arch Neurol-chicago, Chicago 62, 1556-1560.

[43] Burdo JR, Chen Q, Calcutt NA, Schubert D (2009) The pathological interaction between diabetes and presymptomatic Alzheimer's disease. Neurobiol. Aging 30, 1910-1917.

[44] Ott A, Stolk RP, Hofman A, VanHarskamp F, Grobbee DE, Breteler MMB (1996) Association of diabetes mellitus and dementia: The Rotterdam study. Diabetologia 39, $1392-1397$.

[45] Massaia M, Di Ceva AP, Cappa MBG, Zannella P, Persico D, Ferrario E, Fabris F (2001) Risk factors for dementia of Alzheimer's type: A case-control, retrospective evaluation. Arch. Gerontol. Geriatr. 253-259.

[46] Barnes DE, Yaffe K (2015) The projected effect of risk factor reduction on Alzheimer's disease prevalence. Lancet Neurol. 10, 819-828.

[47] Tolppanen A-M, Solomon A, Kulmala J, Kareholt I, Ngandu T, Rusanen M, Laatikainen T, Soininen H, Kivipelto M (2015) Leisure-time physical activity from mid- to late life, body mass index, and risk of dementia. Alzheimers Dement. 11, 434-443.

[48] Yamada M, Kasagi F, Sasaki H, Masunari N, Mimori Y, Suzuki G (2003) Association between dementia and midlife risk factors: the Radiation Effects Research Foundation Adult Health Study. J. Am. Geriatr. Soc. 51, 410-414.

[49] Sanmugam K (2015) Depression is a Risk Factor for Alzheimer Disease-Review. Res. J. Pharm. Technol. 8, 1056. 
[50] Dufouila C, Seshadri S, Chene G (2014) Cardiovascular Risk Profile in Women and Dementia. J. Alzheimers Dis. 42,.

[51] Lee Y, Back JH, Kim J, Kim S-H, Na DL, Cheong H-K, Hong CH, Kim YG (2009) Systematic review of health behavioral risks and cognitive health in older adults. Int. Psychogeriatrics 22, 174-187.

[52] Singh B, Parsaik AK, Mielke MM, Erwin PJ, Knopman DS, Petersen RC, Roberts RO (2014) Association of Mediterranean diet with mild cognitive impairment and Alzheimer's disease: A systematic review and meta-analysis. J. Alzheimer's Dis. 39, 271282.

[53] Donini LM, De Felice MR, Cannella C (2007) Nutritional status determinants and cognition in the elderly. Arch. Gerontol. Geriatr. 44, 143-153.

[54] Shah R (2013) The Role of Nutrition and Diet in Alzheimer Disease: A Systematic Review. J. Am. Med. Dir. Assoc. 14, 398-402.

[55] Lopes da Silva S, Vellas B, Elemans S, Luchsinger J, Kamphuis P, Yaffe K, Sijben J, Groenendijk M, Stijnen T (2014) Plasma nutrient status of patients with Alzheimer's disease: Systematic review and meta-analysis. Alzheimers. Dement. 10, 485-502.

[56] Woodward MC (2003) Prevention of Alzheimer's disease and other dementias. $J$. Pharmac 33, 138-143.

[57] Akhbardeh M (2008) The role of professional nutrition in treating Alzheimer's disease. FASEB J. 22,

[58] Wolfe MS (2012) Processive proteolysis by $\gamma$-secretase and the mechanism of Alzheimer's disease. Biol. Chem. 393, 899-905. 
[59] Vassar R, Bennett BD, Babu-Khan S, Kahn S, Mendiaz EA, Denis P, Teplow DB, Ross S, Amarante P, Loeloff R, Luo Y, Fisher S, Fuller J, Edenson S, Lile J, Jarosinski MA, Biere AL, Curran E, Burgess T, Louis JC, Collins F, Treanor J, Rogers G, Citron M (1999) Beta-secretase cleavage of Alzheimer's amyloid precursor protein by the transmembrane aspartic protease BACE. Science 286, 735-741.

[60] Serneels L, Dejaegere T, Craessaerts K, Horré K, Jorissen E, Tousseyn T, Hébert S, Coolen M, Martens G, Zwijsen A, Annaert W, Hartmann D, De Strooper B (2005) Differential contribution of the three Aph1 genes to $\gamma$-secretase activity in vivo. Proc. Natl. Acad. Sci. United States Am. 102 , 1719-1724.

[61] De Strooper B, Saftig P, Craessaerts K, Vanderstichele H, Guhde G, Annaert W, Von Figura K, Van Leuven F (1998) Deficiency of presenilin-1 inhibits the normal cleavage of amyloid precursor protein. Nature 391, 387-390.

[62] Masters CL, Gajdusek DC, Gibbs CJJ (1981) The familial occurrence of CreutzfeldtJakob disease and Alzheimer's disease. Brain 104, 535-558.

[63] Glenner GG, Wong CW (1984) Alzheimer's disease: initial report of the purification and characterization of a novel cerebrovascular amyloid protein. Biochem. Biophys. Res. Commun. 120, 885-890.

[64] Bateman RJ, Munsell LY, Morris JC, Swarm R, Yarasheski KE, Holtzman DM (2006) Human amyloid-beta synthesis and clearance rates as measured in cerebrospinal fluid in vivo. Nat. Med. 12, 856-861.

[65] Shibata M, Yamada S, Kumar SR, Calero M, Bading J, Frangione B, Holtzman DM, Miller CA, Strickland DK, Ghiso J (2000) Clearance of Alzheimer's amyloid- $\beta$ 1-40 
peptide from brain by LDL receptor-related protein-1 at the blood-brain barrier. J. Clin. Invest. 106, 1489-1499.

[66] Deane R, Du Yan S, Submamaryan RK, LaRue B, Jovanovic S, Hogg E, Welch D, Manness L, Lin C, Yu J (2003) RAGE mediates amyloid- $\beta$ peptide transport across the blood-brain barrier and accumulation in brain. Nat. Med. 9, 907-913.

[67] Deane R, Zlokovic B V (2007) Role of the blood-brain barrier in the pathogenesis of Alzheimer's disease. Curr. Alzheimer Res. 4, 191-197.

[68] Mawuenyega KG, Sigurdson W, Ovod V, Munsell L, Kasten T, Morris JC, Yarasheski KE, Bateman RJ (2010) Decreased clearance of CNS beta-amyloid in Alzheimer's disease. Science 330, 1774.

[69] Chávez-Gutiérrez L, Bammens L, Benilova I, Vandersteen A, Benurwar M, Borgers M, Lismont S, Zhou L, Van Cleynenbreugel S, Esselmann H, Wiltfang J, Serneels L, Karran E, Gijsen H, Schymkowitz J, Rousseau F, Broersen K, De Strooper B (2012) The mechanism of $\gamma$-Secretase dysfunction in familial Alzheimer disease. EMBO J. 31, 22612274.

[70] Aizenstein HJ, Nebes RD, Saxton JA, Price JC, Mathis CA, Tsopelas ND, Ziolko SK, James JA, Snitz BE, Houck PR, Bi W, Cohen AD, Lopresti BJ, DeKosky ST, Halligan EM, Klunk WE (2008) Frequent amyloid deposition without significant cognitive impairment among the elderly. Arch. Neurol. 65, 1509-1517.

[71] Jan A, Gokce O, Luthi-Carter R, Lashuel HA (2008) The ratio of monomeric to aggregated forms of $A \beta 40$ and $A \beta 42$ is an important determinant of amyloid- $\beta$ aggregation, fibrillogenesis, and toxicity. J. Biol. Chem. 283, 28176-28189. 
[72] Yankner BA, Dawes LR, Fisher S, Villa-Komaroff L, Oster-Granite ML, Neve RL (1989) Neurotoxicity of a fragment of the amyloid precursor associated with Alzheimer's disease. Science 245, 417-420.

[73] Kayed R, Head E, Thompson JL, McIntire TM, Milton SC, Cotman CW, Glabe CG (2003) Common structure of soluble amyloid oligomers implies common mechanism of pathogenesis. Science 300, 486-489.

[74] Lesne S, Koh MT, Kotilinek L, Kayed R, Glabe CG, Yang A, Gallagher M, Ashe KH (2006) A specific amyloid-beta protein assembly in the brain impairs memory. Nature 440, 352-357.

[75] Ladiwala ARA, Litt J, Kane RS, Aucoin DS, Smith SO, Ranjan S, Davis J, Van Nostrand WE, Tessier PM (2012) Conformational differences between two amyloid beta oligomers of similar size and dissimilar toxicity. J. Biol. Chem. 287, 24765-24773.

[76] Townsend M, Shankar GM, Mehta T, Walsh DM, Selkoe DJ (2006) Effects of secreted oligomers of amyloid beta-protein on hippocampal synaptic plasticity: a potent role for trimers. J. Physiol. 572, 477-492.

[77] Walsh DM, Selkoe DJ (2007) A beta oligomers - a decade of discovery. J. Neurochem. 101, 1172-1184.

[78] Haass C, Selkoe DJ (2007) Soluble protein oligomers in neurodegeneration: lessons from the Alzheimer's amyloid beta-peptide. Nat. Rev. Mol. Cell Biol. 8, 101-112.

[79] Balch WE, Morimoto RI, Dillin A, Kelly JW (2008) Adapting proteostasis for disease intervention. Science 319, 916-9.

[80] Somavarapu AK, Kepp KP (2015) Direct Correlation of Cell Toxicity to Conformational 
Ensembles of Genetic Abeta Variants. ACS Chem. Neurosci. 6, 1990-1996.

[81] Ono K, Condron MM, Teplow DB (2009) Structure-neurotoxicity relationships of amyloid beta-protein oligomers. Proc. Natl. Acad. Sci. U. S. A. 106, 14745-14750.

[82] Götz J, Eckert A, Matamales M, Ittner LM, Liu X (2011) Modes of A $\beta$ toxicity in Alzheimer's disease. Cell. Mol. Life Sci. 68, 3359-3375.

[83] Walsh DM, Klyubin I, Fadeeva J V, Cullen WK, Anwyl R, Wolfe MS, Rowan MJ, Selkoe DJ (2002) Naturally secreted oligomers of amyloid beta protein potently inhibit hippocampal long-term potentiation in vivo. Nature 416, 535-539.

[84] Glabe CG (2006) Common mechanisms of amyloid oligomer pathogenesis in degenerative disease. Neurobiol. Aging 27, 570-575.

[85] Sciacca MFM, Kotler SA, Brender JR, Chen J, Lee DK, Ramamoorthy A (2012) Twostep mechanism of membrane disruption by $A \beta$ through membrane fragmentation and pore formation. Biophys. J. 103, 702-710.

[86] Lecanu L, Greeson J, Papadopoulos V (2006) Beta-amyloid and oxidative stress jointly induce neuronal death, amyloid deposits, gliosis, and memory impairment in the rat brain. Pharmacology 76, 19-33.

[87] Arispe N, Rojas E, Pollard HB (1993) Alzheimer disease amyloid beta protein forms calcium channels in bilayer membranes: blockade by tromethamine and aluminum. Proc. Natl. Acad. Sci. U. S. A. 90, 567-571.

[88] Bhatia R, Lin H, Lal R (2000) Fresh and globular amyloid beta protein (1-42) induces rapid cellular degeneration: evidence for AbetaP channel-mediated cellular toxicity. FASEB J. 14, 1233-1243. 
[89] Brender JR, Heyl DL, Samisetti S, Kotler S a, Osborne JM, Pesaru RR, Ramamoorthy A (2013) Membrane disordering is not sufficient for membrane permeabilization by islet amyloid polypeptide: studies of IAPP(20-29) fragments. Phys. Chem. Chem. Phys. 15, 8908-8915.

[90] Tiwari MK, Kepp KP (2015) Modeling the Aggregation Propensity and Toxicity of Amyloid- $\beta$ Variants. J. Alzheimer's Dis. 47, 215-229.

[91] Quist A, Doudevski I, Lin H, Azimova R, Ng D, Frangione B, Kagan B, Ghiso J, Lal R (2005) Amyloid ion channels: a common structural link for protein-misfolding disease. Proc. Natl. Acad. Sci. U. S. A. 102, 10427-10432.

[92] You H, Tsutsui S, Hameed S, Kannanayakal TJ, Chen L, Xia P, Engbers JDT, Lipton S a., Stys PK, Zamponi GW (2012) A $\beta$ neurotoxicity depends on interactions between copper ions, prion protein, and N-methyl-D-aspartate receptors. Proc. Natl. Acad. Sci. 109, 17371742.

[93] Caspersen C, Wang N, Yao J, Sosunov A, Chen X, Lustbader JW, Xu HW, Stern D, McKhann G, Yan S Du (2005) Mitochondrial Abeta: a potential focal point for neuronal metabolic dysfunction in Alzheimer's disease. FASEB J. 19, 2040-2041.

[94] Lustbader JW, Cirilli M, Lin C, Xu HW, Takuma K, Wang N, Caspersen C, Chen X, Pollak S, Chaney M, Trinchese F, Liu S, Gunn-Moore F, Lue L-F, Walker DG, Kuppusamy P, Zewier ZL, Arancio O, Stern D, Yan SS, Wu H (2004) ABAD directly links Abeta to mitochondrial toxicity in Alzheimer's disease. Science 304, 448-452.

[95] Manczak M, Anekonda TS, Henson E, Park BS, Quinn J, Reddy PH (2006) Mitochondria are a direct site of A beta accumulation in Alzheimer's disease neurons: implications for 
free radical generation and oxidative damage in disease progression. Hum. Mol. Genet. 15, 1437-1449.

[96] De Strooper B (2014) Lessons from a Failed $\gamma$-Secretase Alzheimer Trial. Cell 159, 721726.

[97] Somavarapu AK, Kepp KP (2016) Loss of stability and hydrophobicity of presenilin 1 mutations causing Alzheimer's Disease. J. Neurochem.

[98] Cacquevel M, Aeschbach L, Houacine J, Fraering PC (2012) Alzheimer's disease-linked mutations in presenilin- 1 result in a drastic loss of activity in purified $\gamma$-secretase complexes. PLoS One 7, 1-13.

[99] Kepp KP, Dasmeh P (2014) A model of proteostatic energy cost and its use in analysis of proteome trends and sequence evolution. PLoS One 9, e90504.

[100] Karran E, Hardy J (2014) A critique of the drug discovery and phase 3 clinical programs targeting the amyloid hypothesis for Alzheimer disease. Ann. Neurol. 185-205.

[101] Selkoe DJ, Hardy J (2016) The amyloid hypothesis of Alzheimer's disease at 25 years. EMBO Mol. Med. 8, e201606210.

[102] Bouwman FH, Schoonenboom NSM, Verwey NA, van Elk EJ, Kok A, Blankenstein MA, Scheltens P, van der Flier WM (2009) CSF biomarker levels in early and late onset Alzheimer's disease. Neurobiol. Aging 30, 1895-1901.

[103] Price JL, McKeel DWJ, Buckles VD, Roe CM, Xiong C, Grundman M, Hansen LA, Petersen RC, Parisi JE, Dickson DW, Smith CD, Davis DG, Schmitt FA, Markesbery WR, Kaye J, Kurlan R, Hulette C, Kurland BF, Higdon R, Kukull W, Morris JC (2009) Neuropathology of nondemented aging: presumptive evidence for preclinical Alzheimer 
disease. Neurobiol. Aging 30, 1026-1036.

[104] Kepp KP (2012) Bioinorganic chemistry of Alzheimer's disease. Chem. Rev. 112, 51935239.

[105] Drachman DA (2014) The amyloid hypothesis, time to move on: Amyloid is the downstream result, not cause, of Alzheimer's disease. Alzheimer's Dement. 10, 372-380.

[106] Jack CRJ, Knopman DS, Jagust WJ, Shaw LM, Aisen PS, Weiner MW, Petersen RC, Trojanowski JQ (2010) Hypothetical model of dynamic biomarkers of the Alzheimer's pathological cascade. Lancet. Neurol. 9, 119-128.

[107] Gomez-Isla T, Hollister R, West H, Mui S, Growdon JH, Petersen RC, Parisi JE, Hyman BT (1997) Neuronal loss correlates with but exceeds neurofibrillary tangles in Alzheimer's disease. Ann. Neurol. 41, 17-24.

[108] Schmitz C, Rutten BPF, Pielen A, Schafer S, Wirths O, Tremp G, Czech C, Blanchard V, Multhaup G, Rezaie P, Korr H, Steinbusch HWM, Pradier L, Bayer TA (2004) Hippocampal neuron loss exceeds amyloid plaque load in a transgenic mouse model of Alzheimer's disease. Am. J. Pathol. 164, 1495-1502.

[109] Bush AI, Tanzi RE (2008) Therapeutics for Alzheimer's disease based on the metal hypothesis. Neurotherapeutics 5, 421-432.

[110] Morley JE, Farr SA, Banks WA, Johnson SN, Yamada KA, Xu L (2010) A physiological role for amyloid- $\beta$ protein: Enhancement of learning and memory. J. Alzheimer's Dis. 19, $441-449$.

[111] Zou K, Gong J-S, Yanagisawa K, Michikawa M (2002) A novel function of monomeric amyloid beta-protein serving as an antioxidant molecule against metal-induced oxidative 
damage. J. Neurosci. 22, 4833-4841.

[112] Perry G, Cash AD, Smith MA (2002) Alzheimer Disease and Oxidative Stress. J. Biomed. Biotechnol. 2, 120-123.

[113] Pearson HA, Peers C (2006) Physiological roles for amyloid beta peptides. J. Physiol. $575,5-10$.

[114] Yankner BA, Duffy LK, Kirschner DA (1990) Neurotrophic and neurotoxic effects of amyloid beta protein: reversal by tachykinin neuropeptides. Science 250, 279-282.

[115] Plant LD, Boyle JP, Smith IF, Peers C, Pearson HA (2003) The production of amyloid beta peptide is a critical requirement for the viability of central neurons. J. Neurosci. 23, $5531-5535$.

[116] Abramov E, Dolev I, Fogel H, Ciccotosto GD, Ruff E, Slutsky I (2009) Amyloid-beta as a positive endogenous regulator of release probability at hippocampal synapses. Nat. Neurosci. 12, 1567-1576.

[117] Halle A, Hornung V, Petzold GC, Stewart CR, Monks BG, Reinheckel T, Fitzgerald KA, Latz E, Moore KJ, Golenbock DT (2008) The NALP3 inflammasome is involved in the innate immune response to amyloid- $\beta$. Nat. Immunol. 9, 857-865.

[118] Salminen A, Ojala J, Kauppinen A, Kaarniranta K, Suuronen T (2009) Inflammation in Alzheimer's disease: amyloid- $\beta$ oligomers trigger innate immunity defence via pattern recognition receptors. Prog. Neurobiol. 87, 181-194.

[119] Miklossy J (2011) Emerging roles of pathogens in Alzheimer disease. Expert Rev. Mol. Med. 13, 1-34. 
[120] Soscia SJ, Kirby JE, Washicosky KJ, Tucker SM, Ingelsson M, Hyman B, Burton MA, Goldstein LE, Duong S, Tanzi RE, Moir RD (2010) The Alzheimer's Disease-Associated Amyloid $\beta$-Protein Is an Antimicrobial Peptide. PLoS One 5, e9505.

[121] Bu X-L, Yao X-Q, Jiao S-S, Zeng F, Liu Y-H, Xiang Y, Liang C-R, Wang Q-H, Wang X, Cao H-Y, Yi X, Deng B, Liu C-H, Xu J, Zhang L-L, Gao C-Y, Xu Z-Q, Zhang M, Wang L, Tan X-L, Xu X, Zhou H-D, Wang Y-J (2015) A study on the association between infectious burden and Alzheimer's disease. Eur. J. Neurol. 22, 1519-1525.

[122] Lövheim H, Gilthorpe J, Adolfsson R, Nilsson L-G, Elgh F (2015) Reactivated herpes simplex infection increases the risk of Alzheimer's disease. Alzheimer's Dement. 11, 593599.

[123] Maheshwari P, Eslick GD (2015) Bacterial infection and Alzheimer's disease: a metaanalysis. J. Alzheimer's Dis. 43, 957-966.

[124] Cestari JAF, Fabri GMC, Kalil J, Nitrini R, Jacob-Filho W, de Siqueira JTT, Siqueira SRDT (2016) Oral Infections and Cytokine Levels in Patients with Alzheimer's Disease and Mild Cognitive Impairment Compared with Controls. J. Alzheimer's Dis. 1-7.

[125] Jonsson T, Atwal JK, Steinberg S, Snaedal J, Jonsson P V, Bjornsson S, Stefansson H, Sulem P, Gudbjartsson D, Maloney J, Hoyte K, Gustafson A, Liu Y, Lu Y, Bhangale T, Graham RR, Huttenlocher J, Bjornsdottir G, Andreassen OA, Jönsson EG, Palotie A, Behrens TW, Magnusson OT, Kong A, Thorsteinsdottir U, Watts RJ, Stefansson K (2012) A mutation in APP protects against Alzheimer's disease and age-related cognitive decline. Nature 488, 96-99.

[126] Maloney JA, Bainbridge T, Gustafson A, Zhang S, Kyauk R, Steiner P, van der Brug M, 
Liu Y, Ernst JA, Watts RJ, Atwal JK (2014) Molecular mechanisms of Alzheimer disease protection by the A673T allele of amyloid precursor protein. J. Biol. Chem. 289, 3099031000.

[127] Puzzo D, Gulisano W, Palmeri A, Arancio O (2015) Rodent models for Alzheimer's disease drug discovery. Expert Opin. Drug Discov. 10, 703-711.

[128] Qiang W, Yau W-M, Luo Y, Mattson MP, Tycko R (2012) Antiparallel beta-sheet architecture in Iowa-mutant beta-amyloid fibrils. Proc. Natl. Acad. Sci. U. S. A. 109, $4443-4448$.

[129] Lomakin A, Teplow DB, Kirschner DA, Benedek GB (1997) Kinetic theory of fibrillogenesis of amyloid beta-protein. Proc. Natl. Acad. Sci. U. S. A. 94, 7942-7947.

[130] Seubert P, Vigo-Pelfrey C, Esch F, Lee M, Dovey H, Davis D, Sinha S, Schlossmacher M, Whaley J, Swindlehurst C (1992) Isolation and quantification of soluble Alzheimer's betapeptide from biological fluids. Nature 359, 325-327.

[131] Galasko D, Chang L, Motter R, Clark CM, Kaye J, Knopman D, Thomas R, Kholodenko D, Schenk D, Lieberburg I, Miller B, Green R, Basherad R, Kertiles L, Boss MA, Seubert P (1998) High cerebrospinal fluid tau and low amyloid beta42 levels in the clinical diagnosis of Alzheimer disease and relation to apolipoprotein E genotype. Arch. Neurol. 55, 937-945.

[132] Shen J, Kelleher RJ (2007) The presenilin hypothesis of Alzheimer's disease: evidence for a loss-of-function pathogenic mechanism. Proc. Natl. Acad. Sci. U. S. A. 104, 403-409.

[133] De Strooper B (2007) Loss-of-function presenilin mutations in Alzheimer disease. Talking Point on the role of presenilin mutations in Alzheimer disease. EMBO Rep. 8, 141-146. 
[134] Somavarapu AK, Kepp KP (2016) The dynamic mechanism of presenilin-1 function: Sensitive gate dynamics and loop unplugging control protein access. Neurobiol. Dis. 89, $147-156$.

[135] Zhu X, Raina AK, Perry G, Smith MA (2004) Alzheimer's disease: the two-hit hypothesis. Lancet. Neurol. 3, 219-226.

[136] Farlow M, Arnold SE, Van Dyck CH, Aisen PS, Snider BJ, Porsteinsson AP, Friedrich S, Dean RA, Gonzales C, Sethuraman G (2012) Safety and biomarker effects of solanezumab in patients with Alzheimer's disease. Alzheimer's Dement. 8, 261-271.

[137] Doody RS, Thomas RG, Farlow M, Iwatsubo T, Vellas B, Joffe S, Kieburtz K, Raman R, Sun X, Aisen PS, Siemers E, Liu-Seifert H, Mohs R (2014) Phase 3 trials of solanezumab for mild-to-moderate Alzheimer's disease. N. Engl. J. Med. 370, 311-321.

[138] Tayeb HO, Murray ED, Price BH, Tarazi FI (2013) Bapineuzumab and solanezumab for Alzheimer's disease: is the "amyloid cascade hypothesis" still alive? Expert Opin. Biol. Ther. 13, 1075-1084.

[139] Siemers ER, Sundell KL, Carlson C, Case M, Sethuraman G, Liu-Seifert H, Dowsett SA, Pontecorvo MJ, Dean RA, Demattos R (2016) Phase 3 solanezumab trials: Secondary outcomes in mild Alzheimer's disease patients. Alzheimer's Dement. 12, 110-120.

[140] Sevigny J, Chiao P, Williams L, Chen T, Ling Y, O’Gorman J, Hock C, Nitsch RM, Sandrock A (2015) Aducanumab (BIIB037), an anti-amyloid beta monoclonal antibody, in patients with prodromal or mild Alzheimer's disease: Interim results of a randomized, double-blind, placebo-controlled, phase 1b study. Alzheimer's Dement. J. Alzheimer's Assoc. 11, P277. 
[141] Viglietta V, O’Gorman J, Williams L, Tian Y, Sandrock A, Doody R, Salloway S, Barkhof F, Vellas B, Sano M (2016) Randomized, Double-Blind, Placebo-Controlled Studies to Evaluate Treatment with Aducanumab (BIIB037) in Patients with Early Alzheimer's Disease: Phase 3 Study Design (S1. 003). Neurology 86, S1-003.

[142] Salloway S, Sperling R, Fox NC, Blennow K, Klunk W, Raskind M, Sabbagh M, Honig LS, Porsteinsson AP, Ferris S, Reichert M, Ketter N, Nejadnik B, Guenzler V, Miloslavsky M, Wang D, Lu Y, Lull J, Tudor IC, Liu E, Grundman M, Yuen E, Black R, Brashear HR (2014) Two phase 3 trials of bapineuzumab in mild-to-moderate Alzheimer's disease. N. Engl. J. Med. 370, 322-333.

[143] Castellani RJ, Perry G (2012) Pathogenesis and disease-modifying therapy in Alzheimer's disease: the flat line of progress. Arch. Med. Res. 43, 694-698.

[144] Blennow K, Zetterberg H, Rinne JO, Salloway S, Wei J, Black R, Grundman M, Liu E (2012) Effect of immunotherapy with bapineuzumab on cerebrospinal fluid biomarker levels in patients with mild to moderate Alzheimer disease. Arch. Neurol. 69, 1002-1010.

[145] Walsh DM, Thulin E, Minogue AM, Gustavsson N, Pang E, Teplow DB, Linse S (2009) A facile method for expression and purification of the Alzheimer's disease-associated amyloid beta-peptide. FEBS J. 276, 1266-1281.

[146] Stine WB, Jungbauer L, Yu C, LaDu MJ (2011) Preparing synthetic Abeta in different aggregation states. Methods Mol. Biol. 670, 13-32.

[147] Somavarapu AK, Kepp KP (2015) The Dependence of Amyloid-beta Dynamics on Protein Force Fields and Water Models. Chemphyschem 16, 3278-3289.

[148] Deshpande A, Mina E, Glabe C, Busciglio J (2006) Different conformations of amyloid 
beta induce neurotoxicity by distinct mechanisms in human cortical neurons. J. Neurosci. 26, 6011-6018.

[149] Tiwari MK, Kepp KP (2015) Pathogenic properties of Alzheimer's $\beta$-amyloid identified from structure-property patient-phenotype correlations. Dalt. Trans. 44, 2747-2754.

[150] Choi J-S, Braymer JJ, Nanga RPR, Ramamoorthy A, Lim MH (2010) Design of small molecules that target metal-A $\beta$ species and regulate metal-induced $\mathrm{A} \beta$ aggregation and neurotoxicity. Proc. Natl. Acad. Sci. U. S. A. 107, 21990-21995.

[151] Ramamoorthy A, Lim MH (2013) Structural characterization and inhibition of toxic amyloid- $\beta$ oligomeric intermediates. Biophys. J. 105, 287-288. 